\title{
Isolation of Bacteriophages and Determination of their Efficiency in Controlling Ralstonia solanacearum Causing Bacterial Wilt of Tomato
}

\author{
M. D. Kalpage* and D. M. De Costa ${ }^{1}$ \\ Postgraduate Institute of Agriculture \\ University of Peradeniya \\ Sri Lanka
}

\begin{abstract}
Bacterial wilt caused by Ralstonia solanacearum is a devastating disease of many economically-important crops. Management of $\underline{R}$. solanacearum is difficult using a single method hence incorporation of a biological component in an integrated programme would be a promising approach. In the present study biocontrol potential of bacteriophages in controlling bacterial wilt of tomato (variety Thilina) was investigated. Bacteriophages were isolated from soil collected from vegetable fields or locations rich with organic matter and a mixture of six different phages were used in the study. Their effectiveness in controlling bacterial wilt caused by two isolates of $\underline{R}$. solanacearum (isolate 6 and AB3) was investigated under planthouse conditions. Bacteriophage mixtures at a concentration of $2.86 \times 10^{6} \mathrm{pfu} / \mathrm{ml}$ were applied to the rhizosphere as a soil drench by several methods. The phage isolates had different lytic patterns on host $R$. solanacearum isolates and varied in their plaque morphology. Percentage wilt incidence by isolate 6 was reduced by 10\%, due to application of the phage mixture immediately before the inoculation of the pathogen or when applied three times as a soil drench. Wilt incidence by isolate AB3 was reduced by $20 \%$ due to the application of the phage mixture by the two methods. Survival of the bacteriophage in soil treated with pahges ranged from $0.2 \times 10^{3}-3.5 \times 10^{4} \mathrm{pfu} / \mathrm{g}$ of soil, after 15 days of the last application of phages.
\end{abstract}

Keywords: Biological control, Lytic pattern, Percentage wilt incidence

\section{INTRODUCTION}

Production of tomato (Solanum lycopersicum) worldwide is affected by biotic and abiotic constraints. Among the biotic constraints, bacterial wilt caused by Ralstonia solanacearum (E.F.Smith), formerly named as Pseudomonas solanacearum has been considered to be the most damaging factor. A large body of information confirms that the bacterial wilt caused by $R$. solanacearum is the most ubiquitous and damaging disease of crops grown in tropical and subtropical countries (Kelman, 1985). The bacterium is well adapted to soil and survives in the rhizosphere. It possesses a diverse range of virulence factors, enters the roots from artificial or natural openings and colonizes vascular tissues resulting in internal and external symptoms leading into complete wilting of the plant. $R$. solanacearum is considered as a species complex comprising of heterogeneous group of related strains. $R$. solanacearum has been subdivided into "races" based on host range and five such races have been classified (Hayward, 1991). Race 1 has the highest number of host species including solanaceous crops (Elphinstone, 2005).

\footnotetext{
1 Department of Agricultural Biology, Faculty of Agriculture, University of Peradeniya, Peradeniya, Sri Lanka Corresponding author: maheshi_kalpage@yahoo.com
} 
In general, control of bacterial diseases is a challenge due to various factors of the pathogen including its genetic variation, ability to overcome plant genetic resistance, development of resistant bacterial strains, ability to reach high populations in a relatively short period of time under conditions favourable for disease development and lack of effective bactericides (Iriarte et al., 2012). Hence, control of bacterial wilt caused by $R$. solanacearum is also a difficult task.

Conventional control measures of bacterial diseases involve a range of cultural practices, aiming to reduce inoculum density of the pathogen, spreading rate of the disease and time interval that the host and pathogen interacts with each other. Other methods to control bacterial pathogens include application of chemicals such as insecticides (for the control of insect vectors), antibiotics (e.g. tetracycline and streptomycin) and copper fungicides. However, presence of many plant pathogenic bacteria resistant to copper and antibiotics is a common problem (Ronald, 2011). Bacteriophages (phages) offer an alternative to conventional management strategies for controlling bacterial plant diseases (Balogh et al., 2008; Addy et al., 2012). Phages are viruses that specifically infect bacteria, yet have no direct negative effects on animals or plants. Infection of a bacterium by a virulent phage typically results in rapid viral replication, followed by the lysis of the bacterium and the release of numerous progeny phages. These phages can then proceed to infect neighbouring bacteria. Therefore, the numbers of phage will expand when target pathogens are encountered and the therapy will essentially be amplified in response to the bacterial infection. Potential of isolating bacteriophages from different environmental sources (e.g. river water, soil, phyllosphere etc.) and efficiency of them in controlling plant pathogenic bacteria, namely cabbage rot caused by Xanthomonas campestris pv. campestris (Mallmann and Hemstreet, 1924), blackleg disease of potato caused by Pectobacterium carotovorum subsp. atrospeticum (Kotila and Coons, 1925) and bacterial spot disease on tomato and pepper caused by Xanthomonas campestris pv. vesicatoria (Flaherty et al., 2000) have been reported.

The present study was conducted with the objectives of isolating potential bacteriophages as biological control agents of $R$. solanacearum and determining their efficiency in controlling bacterial wilt of tomato under in vitro and in vivo conditions.

\section{METHODOLOGY}

The laboratory and planthouse experiments were conducted at the Department of Agricultural Biology, Faculty of Agriculture, University of Peradeniya, Peradeniya.

\section{Isolation of $\boldsymbol{R}$. solanacearum}

Tomato plants of varieties Thilina, T-245, KWR and Marglobe showing typical wiltsymptoms were collected from selected fields in mid country wet zone (Gampola, Gampolawela), mid country intermediate zone (Kolabissa, Gampolawela, Kottagasmula, Naula, and Thalathu Oya) and low country dry zone (Kithulhitiyawa, Kalundewa) of Sri Lanka. Bacterial ooze collected from surface-sterilized stems of the wilted tomato plants were plated on Nutrient Agar plates. A total of 20 bacterial isolates were purified and those isolates were subjected to biochemical and molecular methods for confirmation as $R$. solanacearum isolates. To determine Gram reaction both Gram staining and 3\% KOH test were done. Isolates were grown on selective media namely, sucrose peptone agar (SPA), 
semi selective medium, South Africa (SMSA) and Kelman's 2,3,5-triphenyl tetrazolium chloride (TZC). As molecular methods, PCR based identification was done for the confirmation of the isolates using BP4-R/BP4-L and PS-1S-R/PS-1S-F primers which are specific to $R$. solanacearum (Lee and Wang, 2000; Lee et al., 2001). The primer sequences for BP4-R and BP4-L were (5'-GACGACATCATTTCCACCGGGCG-3') and (5'GGGTGAGATCGATTGTCTCCTTG-3'), respectively and the expected PCR product size was 1100 bp. PS-1SR and PS-1S-F primers which are specific to $R$. solanacearum race 1 were used for the identification of $R$. solanacearum isolates. Base pair sequences of the primers PS-1S-R and PS-1S-F were 5'-CGCAACGCTGGATGAACCC-3' and 5'CAGACGATGCGAAGCCTGAC-3' respectively and the expected size of the PCR product was 1070 bp (Lee et al., 2001).

\section{Isolation of bacteriophages}

Bacteriophages were isolated from soil samples collected from fields at different locations e.g. Thalatu-Oya (agroecological zone IM3c), Pallekele (agroecological zone IM3a) and Peradeniya (agroecological zone WM2b) representing soils managed under different crop management practices (Table 1). Bacteriophages were isolated according to the method described by Crosse and Hingorani (1958). CPG medium was used as the basal medium for growing the lawn of host bacteria and isolating bacteriophages. Isolates of bacteriophage were separately-identified based on plaque morphology. Accordingly, six bacteriophage isolates were identified and a mixture of the six isolates was used in the biocontrol assays of the present study. Identified bacteriophage isolates were stored in $\mathrm{SM}$ buffer $(\mathrm{NaCl} 5.8 \mathrm{~g}$, $\mathrm{MgSO}_{4} 7 \mathrm{H}_{2} \mathrm{O} 2.0 \mathrm{~g}, 1 \mathrm{M}$ Tris $\mathrm{HCl}(\mathrm{pH} 7.4) 50 \mathrm{ml}$ and $2 \%$ gelatin $5 \mathrm{ml}$ per liter) at $4{ }^{\circ} \mathrm{C}$ under dark conditions until future use.

Table 1. Description of phages used in the experiments.

\begin{tabular}{lll}
$\begin{array}{l}\text { Identification code } \\
\text { given for each } \\
\text { bacteriophage }\end{array}$ & $\begin{array}{l}\text { Location of Sampling Area } \\
\text { Cropping systems practiced in the fields } \\
\text { from which the bacteriophages were } \\
\text { collected }\end{array}$ \\
$\mathrm{F}$ & Peradeniya (WM2b) & $\begin{array}{l}\text { Organic matter rich soil uncultivated leaf } \\
\text { litter area } \\
\text { Organically-cultivated Tomato (Solanum } \\
\text { lycopersicum) field }\end{array}$ \\
$\mathrm{J}$ & Pallekele (IM3a) & $\begin{array}{l}\text { Home garden having vegetables } \\
\text { Organically-cultivated Okra (Abelmoscus } \\
\text { esculentus L.) field }\end{array}$ \\
$\mathrm{O}$ & Iriyagama (WM2b) & $\begin{array}{l}\text { Banana (Musa sp.) grown area } \\
\text { Oallekele (IM3a) }\end{array}$ \\
$\mathrm{P}$ & Pallekele (IM3a) & $\begin{array}{l}\text { Organically-cultivated Brinjal (Solanum } \\
\text { melongina) field }\end{array}$ \\
\hline
\end{tabular}

\section{Determining the broad spectrum ability of phages}

Phage typing was done in vitro to determine the lysing ability of each bacteriophage isolate listed in Table 1 against the 19 isolates of $R$. solanacearum. The $R$. solanacearum isolates 
were streaked separately as a thick smear on well-dried double layer agar plates. Once the streaks have dried completely, a $10 \mu \mathrm{l}$ phage suspension (using a micropipette) was spot inoculated close to one end of the streak. The phage inocula were allowed to dry completely, incubate at $37{ }^{\circ} \mathrm{C}$ for 1-2 days and clear, lysed areas around the spot inoculations were observed.

\section{Establishment of tomato plants}

Tomato nurseries were prepared in Polyurethane (Rigiform) blocks. A commercial compost mixture (purchased from Hadabima sales centre at Gannoruwa) was sterilized by autoclaving and used as the potting medium. Seeds of tomato (variety Thilina) were treated with Thiram $80 \% \mathrm{WP}$ (Tetramethylthiuram disulfide) at a rate of $5 \mathrm{~g} / \mathrm{kg}$ to prevent seed-borne fungal pathogens. Tomato seeds were sown and watering was done as needed. Potting, medium was treated with Thiram solution (Thiram $80 \%$ WP diluted in water to apply in a rate of $70 \mathrm{~g} / 50$ $1 / 10 \mathrm{~m}^{2}$ ) one week after sowing the seeds. Seedlings were transplanted at three leaf-stage (i.e. 4-5 weeks after sowing) in black polyethylene bags $(16 \mathrm{~cm}$ in height and $16 \mathrm{~cm}$ in diameter). Potting medium was a mixture of commercial compost, top soil and coir dust at a ratio of $2: 2: 1$. The bags were filled with the potting medium treated with Thiram (Thiram $80 \%$ WP diluted in water to apply in a rate of $70 \mathrm{~g} / 50 \mathrm{l} / 10 \mathrm{~m}^{2}$ ) one day prior to transplanting. The basal fertilizer application was done at a rate of $65 \mathrm{~kg} / \mathrm{ha}$ Urea, $325 \mathrm{~kg} / \mathrm{ha}$ TSP and $65 \mathrm{~kg} / \mathrm{ha}$ MOP as recommended by the Department of Agriculture, Sri Lanka.

\section{Inoculation with $R$. solanacearum}

Two weeks after transplanting, tomato plants were inoculated with $R$. solanacearum according to the method described by Abdhullah and Rahman (1998) as follows. Tomato plants were kept without watering for 24 hours and roots of each plant were cut $1 \mathrm{~cm}$ away from the base of the stem diagonally. Out of the 19 isolates of $R$. solanacearum, two isolates, namely AB3 and 6 were used for inoculation after confirming their virulence by in vitro (TZC test) and in vivo (inoculating to tomato plants) tests. Approximately $10 \mathrm{ml}$ of an aqueous cell suspension of each $R$. solanacearum isolate was poured around the base of the stem. The OD value of the above bacterial suspension was adjusted spectophotometrically to reach OD of 0.26 at $600_{\mathrm{nm}}$ (which is approximately $1 \times 10^{8} \mathrm{cfu} / \mathrm{ml}$ ).

\section{Mass preparation of bacteriophages}

Bacteriophages were mass prepared under in vitro conditions as follows: $R$. solanacearum isolate $\mathrm{AB} 3$ was used as the host bacterium to propagate the phages. A volume of $250 \mathrm{ml}$ of CPG broth medium was inoculated with isolate $\mathrm{AB} 3$ and incubated for overnight at $28{ }^{\circ} \mathrm{C}$ in a shaking water bath. Aliquots of $150 \mu \mathrm{l}$ were taken in to microfuge tubes from the six isolates of bacteriophages. Chloroform was added to each tube to have a final concentration of $5 \%(\mathrm{v} / \mathrm{v})$. The microfuge tubes were vortexed and centrifuged at $8000 \mathrm{~g}$ for $20 \mathrm{~min}$ at room temperature (Gill et al., 2003). The supernatants were collected and mixed with the overnight bacterial broth culture. The broth culture was shaken and incubated overnight in a shaking water bath at $28^{\circ} \mathrm{C}$.

The resulted in clear solution containing progeny of bacteriophages was centrifuged with 5\% $\mathrm{v} / \mathrm{v}$ chloroform at $8000 \mathrm{~g}$ under room temperature. Supernatants of the six bacteriophage isolates were collected and added into $1000 \mathrm{ml}$ of sterile tap water to have a bacteriophage titer of $2.86 \times 10^{6} \mathrm{pfu} / \mathrm{ml}$. The titre of the final mixture of the bacteriophages was calculated 
by plating serially diluted phage mixture on a lawn of host bacteria using double layer agar plates.

\section{Determination of the efficiency of phage mixture in controlling bacterial wilt}

Isolates 6 and AB3 of R.solanacearum were used for inoculation of separate sets of tomato plants. Bacteriophages were mass propagated using isolate AB3 as the host bacterial cells. The treatment structure used for one set of plants (inoculated with one isolate of $R$. solanacearum) was as follows:

P3times - The phage mixture was applied thrice to the soil (twice before the inoculation and once after the inoculation) with a 2 day interval between each application of bacteriophages

RS+ P3times - The phage mixture was applied thrice to the soil (twice before the inoculation and once after the inoculation) with a 2 day interval between each application of bacteriophages and inoculated with $R$. solanacearum (isolate 6 )

P14d(BI)- The phage mixture was applied on the $14^{\text {th }}$ day after transplanting RS+ P14d(BI)The phage mixture was applied on the $14^{\text {th }}$ day after transplanting then inoculated with $R$. solanacearum (isolate 6 ) in the same day

RS- Inoculated only with $R$. solanacearum (isolate 6)

Negative control- Neither inoculated with $R$. solanacearum (isolate 6) nor treated with the phage mixture

Same set of treatment structure was duplicated for $R$. solanacearum isolate AB3. Each treatment was replicated ten times according to a Completely Randomized Design. Percentage wilt incidence (number of plants showing wilt symptoms out of total number of plants per given treatment) was recorded. Significance of the treatments was determined by ANOVA and mean separation was done by LSD. The above experiments were conducted twice, independently.

\section{Enumeration of the bacteriophages in soils treated with the phage mixture}

After the completion of the above two experiments, plants were uprooted (at 30 days after transplanting) and soils were tested for the presence of bacteriophages. Three pots were selected randomly from each treatment and soils in the three pots were mixed to get a composite sample. From the composite sample, $2.5 \mathrm{~g}$ of soil was taken and added into flasks separately. A volume of $50 \mathrm{ml}$ of sterilized water was added in to each flask and gently agitate for 10 minutes. Chloroform was added to each beaker to reach a final concentration of $5 \% \mathrm{v} / \mathrm{v}$. The contents in the flasks were shaken gently. An aliquot of $1 \mathrm{ml}$ of slurry was taken from each flask into sterile microfuge tube and added $5 \%$ chloroform $(\mathrm{v} / \mathrm{v})$. The contents in the microfuge tubes were vortexed and centrifuged at 8,000 g for 20 minutes at 4 ${ }^{\circ} \mathrm{C}$. The supernatants containing the extracted bacteriophages were separately collected in to sterilized microfuge tubes under aseptic conditions. The bacteriophage lysates were serially diluted and phage titer was calculated by plaque assay technique. 


\section{RESULTS AND DISCUSSION}

\section{Confirmation of $R$. solanacearum}

All the 20 isolates were gram negative. Results given by all the $R$. solanacearum isolates when grown on semi-selective media and in vivo pathogenicity are summarized in Table 2.

Table 2. Summary of the results of biochemical and in vivo pathogenicity test

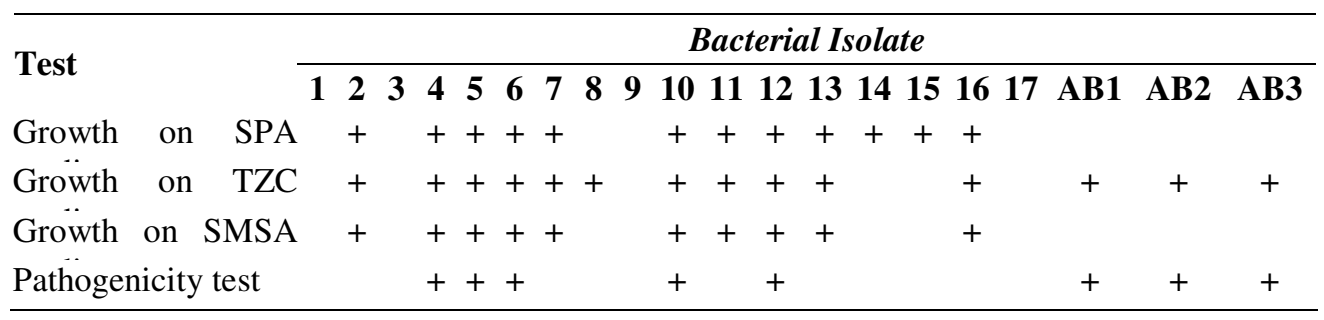

Bacterial colonies developed on SMSA medium were irregular, white and fluidal after an incubation period of 48-72 hours. Round to irregular, creamy white and fluidal colonies were produced on SPA medium. The colony morphology on the above two media was similar to the positive results should be produced by $R$. solanacearum. Appearing of whitish colour colonies with pink centres on TZC medium was an indication that those colonies are virulent $R$. solanacearum. Isolates $1,3,9$ and 17 did not give positive results to any of the pathogenicity tests (Table 2). There could be gram negative endophytes or saprophytes those could get co-isolated during the isolation procedure, which are not $R$. solanacearum but several other Pseudomonas spp. and Enterobacter spp (Ramesh et al., 2009).

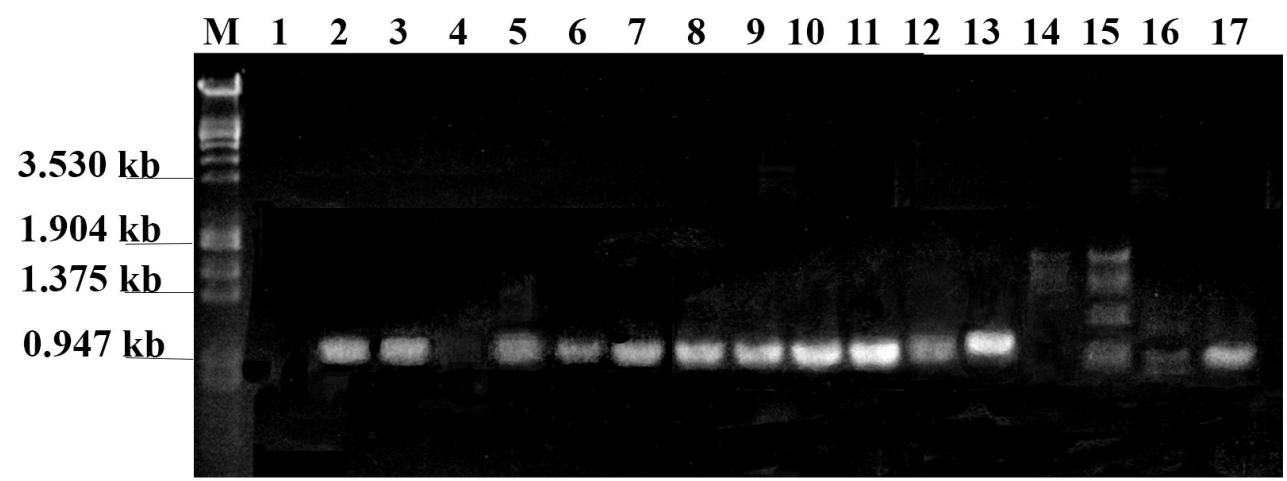

Fig. 1. PCR products given by different isolates of bacteria obtained from infected plant stems when amplified by PS-IS-R and PS-IS-F primers

Fig. 1 shows the PCR products produced by isolates 1-17 when amplified by PS-IS-R and PS-IS-F primers. Isolates 1 and 14 did not result in the PCR product of the expected size which was $1070 \mathrm{bp}$. However, the rest of the isolates were positive for the expected size of the PCR product both PS-IS-R/PS-IS-F and BP-4R/BP-4L (data not shown) indicating they belonged to $R$. solanacearum race 1. PCR amplification was done using the above two primer pairs for isolates $\mathrm{AB} 1, \mathrm{AB} 2$ and $\mathrm{AB} 3$ and they also produced the expected sizes of 
PCR products (data not shown). It confirmed that those three isolates also belonged to race 1 of $R$. solanacearum.

A polyphasic approach based on biochemical tests, semi-selective media and molecular methods was used to identify and select virulent $R$. solanacerum isolates. A number of saprophytic soil borne bacteria could grow on SMSA agar and outcompete the culture medium when $R$. solanacearum population is lesser in the sample than the saprophytic population (Pradhanang et al., 2000). Moreover, the isolates (with different origins) identified by PCR methods as $R$. solanacearum and as virulent isolates by TZC medium may not develop wilt symptoms on the variety of host plant used for inoculation due to variations in pathogenicity (Chandrashekara et al., 2012). Therefore, based on all tests, isolates 4, 5, 6, $10,11,12, \mathrm{AB} 1, \mathrm{AB} 2$, and $\mathrm{AB} 3$ were identified as virulent $R$. solanacearum isolates.

\section{Determination of broad spectrum ability of phages}

The bacteriophage isolates showed a variation in plaque morphology on host bacterium isolate 6 (Fig. 2).
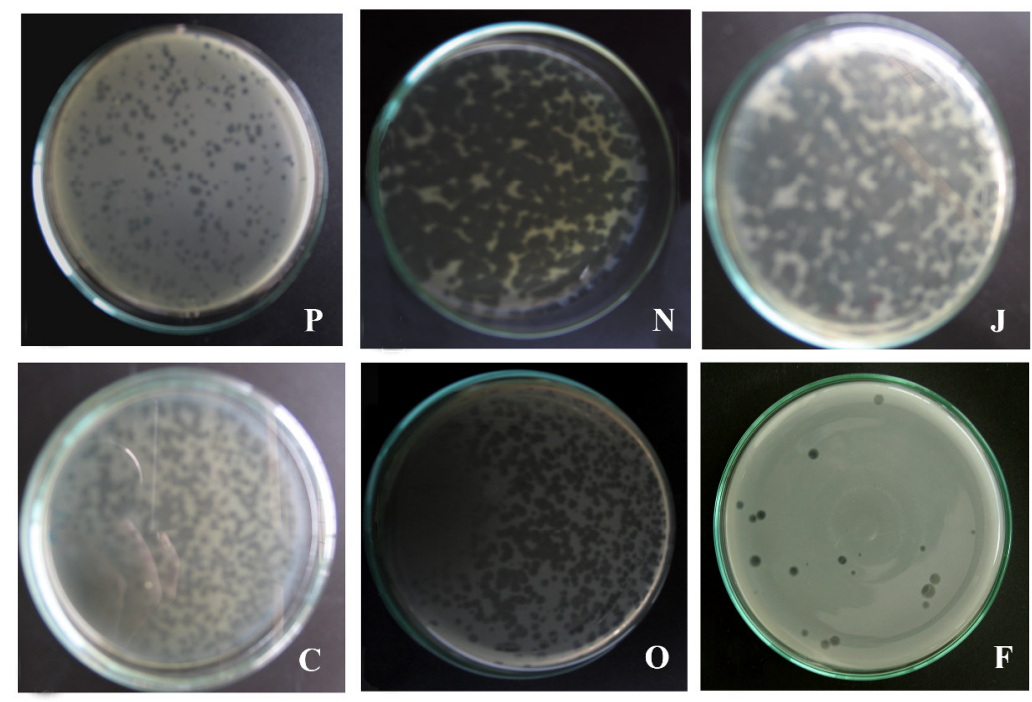

Fig. 2. Variation of plaque morphology produced by six selected phages on doubled layer agar plates, when R.solanacearum isolate 6 (i.e. P, N, J, C, O and F) was used as the host bacterium

Table 3 summarizes the phage typing results of the six phage isolates tested on 19 isolates of R. solanacearum. 
Table 3. Broad spectrum ability of lysis of isolated bacteriophages against R.solanacearum isolates

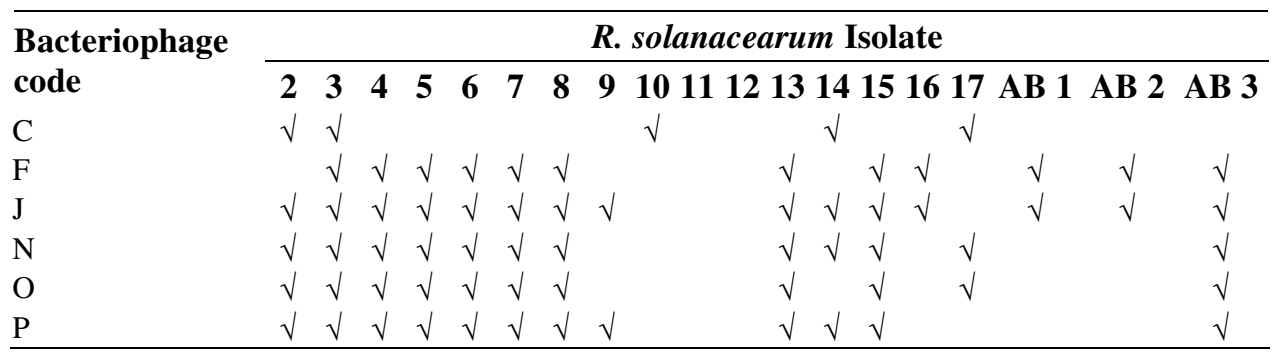

A heterogenous lytic pattern was shown by the six bacteriophage isolates against the 19 isolates of $R$. solanacearum. However, isolates 11 and 12 of $R$. solanacearum were not lysed by any of the bacteriophage isolates. All the phage isolates were effective against $R$. solanacearum isolate 3 . Nine isolates of $R$. solanacearum were lysed by five phage isolates out of the six. $R$. solanacearum isolate 10 was lysed by one isolate of phage mixture.

According to Hayward (2000), R. solanacearum has an unusually wide host range covering over 200 plant species belonging to more than 50 botanical families, and shows great phenotypic and genotypic diversity between strains. Therefore, determining the host range of each phage isolate should be a prerequisite before deciding on the member isolates to be used in the phage mixture. Determining the host range of each phage enables to design of a phage mixture capable of infecting all known pathogenic strains involved in the disease. Although the host range of most phages is usually narrow, bacteria isolated from the plant environment should be tested for lysis by the putative phages to be used as biological control agent, to ensure a minimal impact of the phages on the wider microbial community and potential commensal strains (Frampton et al., 2012). Bouzar et al. (1999) used 26 bacteriophages to type approximately 100 Xanthomonas euvesicatoria strains isolated from various countries in the Caribbean region including Central America, and identified at least 26 different phage lysis patterns. Our results on phage typing also showed varying lysis patterns between the used bacteriophage and $R$. solanacearum isolates, indicating the specific nature of each phage and bacterial combination.

\section{Efficiency in controlling bacterial wilt by phage mixture under in vivo conditions}

Percentage wilt incidence did not differ significantly among the treatments until $7^{\text {th }}$ day in the plants inoculated with isolate 6 , however, the wilt incidence differed significantly among treatments thereafter $(p<0.0001)$. Plants inoculated with isolate AB3, showed a significant difference of $\%$ wilt incidence among the treatments from $5^{\text {th }}$ day after inoculation. 


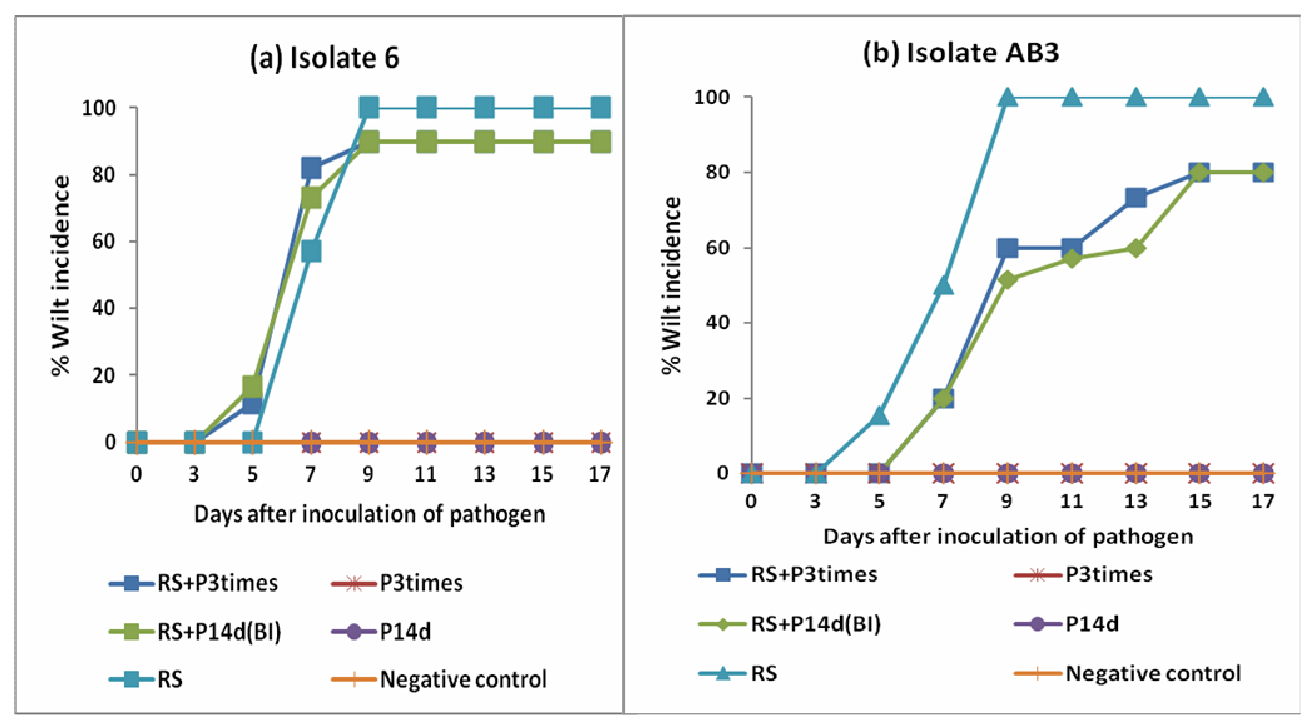

Fig. 3. Percentage wilt incidence shown by tomato (var. Thilina) when inoculated with two isolates of $R$. solanacearum and treated with different methods of phage treatments

As expected the plants treated with the negative control and only with the phage mixture (e.g. P3 times and P14d (BI) did not develop wilt disease (Fig. 3). Only the plants inoculated with isolate $\mathrm{AB} 3$ and applied with the phage mixture by two methods [RS+P3times and $\mathrm{RS}+\mathrm{P} 14 \mathrm{~d}(\mathrm{BI})]$ significantly reduced $(\mathrm{p}<0.05)$ the \% wilt incidence. This indicated the efficiency of reducing wilt development by the two application methods of phage mixture, when the plants are infected with isolate AB3. However, the two application methods had no significant difference on the reduction of wilt incidence when plants are inoculated with either of the isolates. Even though a $10 \%$ reduction of wilt incidence was observed in plants inoculated with isolate 6 , by the two application methods, a significant reduction was not achieved due to phage treatments. However, a 20\% reduction of wilt incidence was achieved due to treatments of phage mixtures in plants inoculated with isolate $\mathrm{AB} 3$, which was a significant reduction.

The two isolates showed a difference in wilt symptom development. Initial wilt development was shown five days after inoculation with isolate 6 , whereas symptom development occurred 3 days after the inoculation with isolate $\mathrm{AB} 3$, indicating the varying degree of virulence of the two $R$. solanacearum isolates. It confirmed the necessity of an effective phage mixture for control of bacterial wilt under natural infections. Adriaenssens et al. (2012) have reported success of using a mixture of phages against Dickeya solani and Pectobacterium atrosepticum to control soft rot caused by both species.

According to three consecutive field trials done by Balogh and Jones (2003) nonformulated phage had reported 9-20\% reduction in bacterial spot on tomato in comparison to the nontreated plants. It is reported that the plants treated with casecrete-formulated phage had reduced $12-43 \%$ of the tomato bacterial spot disease (Frampton et al., 2012). Accordingly, the disease reduction achieved by the present study is in a reasonably acceptable level. 
Iriarte et al. (2012) has applied a phage mixture at various time points prior and following the application of $R$. solanacearum to the soil. According to Iriarte et al. (2012) the most effective wilt control had been achieved when a phage mixture was applied immediately after inoculation of the pathogen. The same study reported that there was no effect on disease control when a single phage was applied immediately after inoculation of the pathogen. Findings of the present study agree with the observations of Iriarte et al. (2012). According to Fig. 3 of the present study, the lowest percentage wilt development (highest disease reduction) was shown when the phage mixture was applied immediately before inoculation of the pathogen. According to Iriate et al. (2012) phage mixtures as well as the single phage treatments were less effective in controlling bacterial wilt of tomato when applied 3 days before or after inoculation of the plants. Success of the phage treatment has shown variable efficiencies with the application time and no. of times. For example, when controlling aboveground bacterial pathogens, Civerolo and Keil (1969) achieved a significant reduction of peach bacterial spot only if the phage treatment was applied one hour or one day before inoculation with the pathogen. Bergamin Filho and Kimati (1981) reported that the highest disease reduction was achieved when the phages were applied at the day of inoculation for the two pathosystems; black rot of cabbage caused by Xanthomonas campestris pv. campestris and bacterial spot of pepper caused by $X$. campestris pv. vesicatoria.

Phage survival and their persistence at the required site of action are affected by conditions such as $\mathrm{pH}$, temperature, desiccation, rain, and UV. The most damaging factor appears to be UV irradiation in sunlight (Iriarte et al., 2007). In the present study, density of bacteriophages in phage treated soils (approximately 15 days after the last treatment of bacteriophages) ranged from $0.2 \times 10^{3}-3.5 \times 10^{4} \mathrm{cfu} / \mathrm{g}$ of soil. Soils that were not treated with bacteriophages did not show any presence of bacteriophages. In general phages persisted in the rhizosphere and roots of treated plants, although they did decline between ten and a hundred-fold over a 14 day period (Iriarte et al., 2012). Hence, increasing the retention efficiency of bacteriophages in soil, use of formulated phage mixtures and use of phage treatment in combination with other agronomic and/or chemical methods will increase the disease reduction. Marco and Stall (1983) have evaluated phage treatment in combination with copper-mancozeb for the control of Xanthomonas leaf blight of onion and found that combination resulted in enhanced disease control. Considering the potential of bacteriophages in controlling bacterial wilt, future studies should be focused on increasing the efficiency of wilt reduction through improving the application methods or by combining integrated methods.

\section{CONCLUSION}

The present study identified 19 isolates of $R$. solanacearum from wilt-infected tomato plants. Application of a mixture of six phage isolates at a concentration of $2.86 \times 10^{6} \mathrm{pfu} / \mathrm{ml}$ as a soil treatment three times at a two day interval (starting from 14 days after transplanting) and treating the soil immediately before inoculation of the pathogen reduce the wilt incidence at a range of $10-20 \%$.

\section{ACKNOWLEDGEMENT}

This study was supported by NSF grant RG/2007/BT/05. 


\section{REFERENCES}

Abdullah, H. and Rahman, M. A. (1998). Multiplication of Ralstonia solanacearum in Capsicum annuиm. Bacterial Wilt Disease. 309 - 315.

Addy, H.S., Askora, A., Kawasaki, T., Fujie, M. and Yamada, T. (2012). Utilization of filamentous phage RSM3 to control Bacterial wilt caused by Ralstonia solanacearum. Plant Disease. 96(8), 1204 - 1208.

Adriaenssens, E.M., Vaerenberg, J.V., Vandenheuvel, D., Dunon, V., Ceyssens, P.J., Proft, M.D., Kropinski, A.M., Noben, J.P., Maes, M. and Lavigne, R. (2012). T4-Related Bacteriophage LIMEstone Isolates for the Control of Soft Rot on Potato Caused by 'Dickeya solani'. Plosone. 7(3), e33227.

Balogh, B.I., Canteros, B.I., Stall, R.E. and Jones, J.B. (2008). Control of citrus canker and citrus bacterial spot with bacteriophages. Plant Disease. 92, 1048 - 52.

Balogh, B. and Jones, J.B. (2003). Improved Efficacy of Newly Formulated Bacteriophages for Management Bacterial Spot on Tomato. Plant Disease. 87(8), 949 - 954.

Bergamin Filho, A. and Kimati, H. (1981). Estudos sobre um bacteriofago isolado de Xanthomonas campestris . II. Seu emprego no controle de X. campestris e X. vesicatoria. Sum Phytopath. 7, 35 - 43.

Bouzar, H., Jones, J.B., Stall, R.E., Louws, F.J., Schneider, M., Rademaker, J.L.W. de Bruijn F.J. and Jackson, L.E. (1999). Multiphasic analysis of xanthomonads causing bacterial spot disease on tomato and pepper in the Caribbean and Central America: evidence for common lineages within and between countries. Phytopathology. 89(4), 328 - 335.

Chardrashekara, K.N., Prasanna, M.K. and Saroja, S. (2012). Aggressiveness of Ralstonia solanacearum isolates on Tomato. Journal of Experimental Science. 3(9), 05 - 09.

Civerolo, E.L. and Keil, H.L. (1969). Inhibition of bacterial spot of peach foliage by Xanthomonas pruni bacteriophage. Phytopathology. 59, 1966 - 1967.

Cross, J.E. and Hingorani, M.K. (1958). A method for isolating Pseudomonas mors. prunorum phages from soil. Nature. 181, 60 - 61.

Elphinstone, J.G. (2005). The current bacterial wilt situation: a global overview. pp. 9-28. In: Allen, C., Prior, P., Hayward, A., and Elphinstone, J.G. (Ed.). Bacterial Wilt Disease and the Ralstonia solanacearum Species Complex, American Phytopathological Society. St. Paul, MN, USA.

Flaherty, J.B., Jones, J.B., Harbaugh, B.K., Somodi, G.C. and Jackson, L.E. (2000). Control of Bacterial Spot on Tomato in the Green House \& Field with H-mutant bacteriophages. HortScience. 35(5), 882 - 884.

Frampton, R.A., Pitman, A.R. and Peter, C.F. (2012). Advances in Bacteriophage-Mediated Control of Plant Pathogens. International Journal of Microbiology. p11.doi:10.1155/2012/326452 
Gill, J.J., Svircev, A.M., Smith, R., and Castle, A.J. (2003). Bacteriophages of Erwinia amylovora. Applied Environmental Microbiology. 69(4), 2133 - 2138.

Hayward, A.C. (1991). Biology and Epidemiology of Bacterial Wilt Caused by Pseudomonas solanacearum. Annual Reviews of Phytopathology. 29, 65 - 87.

Hayward, A.C. (2000). Ralstonia solanacearum. Vol. 4, pp. 32-42. In: Lederberg, J.(Ed) Encyclopedia of Microbiology. Academic Press. San Diego,CA.

Iriarte, F.B., Balogh, B., Momol, M.T., Smith, L.M., Wilson, M. and Jones, J.B. (2007). Factors Affecting Survival of Bacteriophage on Tomato Leaf Surfaces. Applied and Environmental Microbiology. 76(6), 1704 - 1711.

Iriarte, F.B., Obradovic, A., Wernsing, M.H., Jackson, L.E., Balogh, B., Hong, J A., Momol, M.T., Jones, J.B. and Vallad, G.E. (2012). Soil-based systemic delivery and phyllosphere in vivo propagation of bacteriophages. Bacteriophage. 2(4), 215 - 224.

Kelman, A. (1985). Plant pathology at the crossroads. Annual Review of Phytopathology. 23, $1-11$.

Kotila J.E. and Coons G.H. (1925). Investigations on the blackleg disease of potato. Michigan Agricultural Experimental Station Technical Bulletin. 67, 3 - 29.

Lee, Y. and Wang, C. (2000). The Design of specific promers for the detection of Ralstonia solanacearum in soil samples by polymerase chain reaction. Botanical Bulletin- Academia Sinica Taipei. 41, $121-128$.

Lee, Y., Fan, S., Chiu, L. and Hsia, K. (2001). Isolation of an insertion sequence from $R$. solanacearum race 1 and its potential use for strain characterization and detection. Applied and Environmental Microbiology. 67, 3943 - 3950.

Mallmann, W. L. and Hemstreet, C. (1924). Isolation of an inhibitory substance from plants. Journal of Agricultural Research. 28(6), 599 - 602.

Marco, G.M. and Stall, R.E. (1983). Control of bacterial spot of pepper initiated by strains of Xanthomonas campestris pv. vericatoria that differ in sensitivity to copper. Plant Diseases. 67, $779-781$.

Pradhanang, P. M., Elphinstone, J. G. and Fox, R. T. (2000). Sensitive detection of Ralstonia solanacearum in soil: a comparison of different detection techniques. Plant Pathology. 49(4), $414-422$.

Ramesh, R., Joshi, A. A., and Ghanekar, M. P. (2009). Pseudomonads: major antagonistic endophytic bacteria to suppress bacterial wilt pathogen, Ralstonia solanacearum in the eggplant (Solanum melongena L.). World Journal of Microbiology and Biotechnology. 25, $47-55$.

Ronald, P. (2011). Plant Genetics, Sustainable Agriculture and Global Food Security. Genetics. 188(1), 11 - 20. 